\title{
Model Komunikasi Interpersonal Orangtua terhadap Anak Autis
}

\author{
Syahrul Abidin* \\ Program Studi Ilmu Komunikasi, Fakultas Ilmu Sosial \\ Universitas Islam Negeri Sumatera Utara, Indonesia
}

Diterima: Maret 2019; Disetujui: Maret 2019; Dipublish: April 2019

*E-mail: syahrul12@gmail.com

\begin{abstract}
Abstrak
Komunikasi memiliki peranan penting dalam kehidupan manusia, sejak kecil manusia telah berkomunikasi melalui keberadaan orangtua. Peran orangtua sangat menentukan proses perkembangan komunikasi dalam diri seorang anak. Namun tidak semua anak terlahir dalam keadaan yang normal, diantaranya ada yang dianugerahi seorang anak berkebutuhan khusus seperti gangguan autis. Padahal setiap anak memiliki potensi dalam dirinya yang jika tidak disadari dan diperhatikan justru menyebabkan ketidakpercayaan diri pada anak tersebut, proses perkembangan diri yang lambat, dan beberapa permasalahan yang secara umum terdapat pada anak dengan gangguan autis adalah pada aspek sosial dan komunikasi yang sangat kurang atau lambat. Tulisan ini menitikberatkan pada pembahasan model komunikasi interpesonal dalam mengembangkan potensi diri anak gangguan autis. Dengan metode studi dokumen yang memanfaatkan berbagai literatur penelitian terkait, serta teknik analisis yang dilakukan dengan mengorganisasikan serta mereduksi data, kemudian mengkategorikan data, memformulasi hingga menarik kesimpulan. Hasil penelitian dari tulisan ini menunjukkan bahwa banyak model komunikasi harus menyesuaikan dengan karakteristik gangguan autis yang dialami oleh masing-masing anak.
\end{abstract}

Kata Kunci: Model Komunikasi Interpersonal, Orangtua, Anak Autis.

\begin{abstract}
Communication has an important role in human life, since childhood, humans have communicated through the presence of parents. The role of parents greatly determines the process of developing communication in a child. But not all children are born in a normal state, including those who are blessed with a child with special needs such as autism. Even though every child has the potential in him, if he is not aware and cared for, it causes self-distrust in the child, a slow process of self-development, and some problems that are generally found in children with autistic disorders are in the social and communication aspects that are very lacking or slow. This paper focuses on discussing the model of interpersonal communication in developing the self potential of autistic disorder children. With document study methods that utilize various related research literature, as wel l as analytical techniques carried out by organizing and reducing data, then categorizing data, formulating to draw conclusions. The results of this paper indicate that many communication models must adapt to the characteristics of autistic disorders experienced by each child.
\end{abstract}

Keywords: Interpersonal Communication Model, Parent, Autistic Children.

How to Cite: Abidin. S (2019). Model Komunikasi Interpersonal Orangtua terhadap Anak Autis. Journal of Education, Humaniora and Social Sciences (JEHSS). 1 (3): 188-195.

\section{PENDAHULUAN}

Sejak dilahirkan manusia hidup dalam suatu lingkungan tertentu yang menjadi wadah kehidupannya. Ia memerlukan bantuan dari orang lain disekitarnya dengan cara melakukan komunikasi. Dapat dikatakan bahwa secara kodrati manusia merasa perlu berkomunikasi sejak masih bayi sampai akhir hayatnya, atau ungkapan lain untuk menggambarkan hal ini adalah Wwith http://mahesainstitute.web.id/ojs2/index.php/jehss

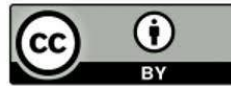


bahwa secara empiris tiada kehidupan tanpa komunikasi. Salah satu hal yang menarik untuk dibahas pada kajian keilmuan komunikasi adalah model komunikasi dalam mengembangkan potensi anak yang mengidap gangguan autis.

Tanggapan dan opini umum berpendapat bahwasannya komunikasi secara lisan merupakan cara yang paling mudah untuk mempelajari dan menguasai bahasa. Berkomunikasi melalui berbicara adalah adalah cara yang terbaik. Kemudian yang menjadi permasalahan yang sangat mendasar ketika ternyata anak dalam perkembangannya tidak mampu melakukan kegiatan komunikasi verbal secara normal. Kondisi tersebut menjadi sulit manakala orang tua tidak memiliki upaya keras untuk mencari solusi agar anak menjalani hidup secara layak dengan keterbatasan kemampuan komunikasinya (Laili, 2013).

Ketidakpahaman orang tua dalam menangani situasi pada anak yang mengalami gangguan autis ini dapat membahayakan tumbuh kembangnya diri anak, disebabkan rendahnya pengetahuan akan gangguan autis, mulai dari varian gangguan autis yang dialami anak, kemampuan pola interaksi yang kurang tepat dari orang tua sehingga menyebabkan terabaikannya potensi yang dimiliki pada diri sang anak tersebut. Padahal setiap manusia terlahir dengan potensi diri yang jika diperhatikan dan dikembangkan dengan baik akan menghasilkan karya yang luar biasa. Dibutuhkan kemampuan komunikasi interpersonal yang tepat dari orang tua untuk dapat membimbing anak yang mengalami gangguan autis menemukan potensi dirinya. Tulisan ini akan membahas model komunikasi interpersonal yang dapat dijadikan refrensi bagi orang tua maupun kalangan akademis disipilin ilmu komunikasi.

Menurut DeVito Komunikasi interpersonal adalah komunikasi yang terjadi antara dua orang yang telah menjalin hubungan, orang yang dengan suatu cara "terhubung" atau mereka yang terlibat dalam hubungan yang erat (Yohannawati, 2013). Sedangkan menurut Alo Liliweri, Komunikasi interpersonal merupakan komunikasi yang terjadi antara dua orang atau lebih yang terhitung dalam bentuk kelompok kecil. Dengan pengertian lain, komunikasi antarpribadi yaitu proses pengiriman pesan dari orang satu terhadap orang lain yang dituju dengan efek dan timbal balik yang langsung (Liliweri, 2011).

Komunikasi interpersonal mungkin mempunyai beberapa tujuan. Di sini akan dipaparkan 6 tujuan, antara lain (Muhammad, 2005), yaitu pertama adalah menemukan Diri Sendiri, Salah satu tujuan komunikasi interpersonal adalah menemukan personal atau pribadi. Bila kita terlibat dalam pertemuan interpersonal dengan orang lain kita belajar banyak sekali tentang diri kita maupun orang lain. Komunikasi interpersonal memberikan kesempatan kepada kita untuk berbicara tentang apa yang kita sukai, atau mengenai diri kita. Adalah sangat menarik dan mengasyikkan bila berdiskusi mengenai perasaan, pikiran, dan tingkah laku kita sendiri. Dengan membicarakan diri kita dengan orang lain, kita memberikan sumber balikan yang luar biasa pada perasaan, pikiran, dan tingkah laku kita. Maka melalui komunikasi interpersonal inilah orang tua bisa membantu anaknya yang mengalami gangguan autis untuk dapat lebih mengenali dan menemukan jati diri sang anak.

Kedua, Menemukan Dunia Luar, Hanya komunikasi interpersonal menjadikan kita dapat memahami lebih banyak tentang diri kita dan orang lain yang berkomunikasi dengan kita. Banyak informasi yang kita ketahui datang dari komunikasi interpersonal, meskipun banyak jumlah informasi yang datang kepada kita dari media massa hal itu seringkali didiskusikan dan akhirnya dipelajari atau didalami melalui interaksi interpersonal.

Ketiga, Membentuk Dan Menjaga Hubungan Yang Penuh Arti, Salah satu keinginan orang yang paling besar adalah membentuk dan memelihara hubungan dengan orang lain. Banyak dari waktu kita pergunakan dalam komunikasi interpersonal diabadikan untuk membentuk dan menjaga hubungan sosial dengan orang lain

Keempat, Berubah Sikap Dan Tingkah Laku, Banyak waktu kita pergunakan untuk mengubah sikap dan tingkah laku orang lain dengan pertemuan interpersonal. Kita boleh menginginkan mereka memilih cara tertentu, misalnya mencoba diet yang baru, membeli barang tertentu, melihat film, menulis membaca buku, memasuki bidang tertentu dan percaya bahwa sesuatu itu benar atau salah. Kita banyak menggunakan waktu waktu terlibat dalam posisi interpersonal. 
Kelima, Untuk Bermain Dan Kesenangan, Bermain mencakup semua aktivitas yang mempunyai tujuan utama adalah mencari kesenangan. Berbicara dengan teman mengenai aktivitas kita pada waktu akhir pekan, berdiskusi mengenai olahraga, menceritakan cerita dan cerita lucu pada umumnya hal itu adalah merupakan pembicaraan yang untuk menghabiskan waktu. Dengan melakukan komunikasi interpersonal semacam itu dapat memberikan keseimbangan yang penting dalam pikiran yang memerlukan rileks dari semua keseriusan di lingkungan kita.

Keenam, Untuk Membantu, Ahli-ahli kejiwaan, ahli psikologi klinis dan terapi menggunakkan komunikasi interpersonal dalam kegiatan profesional mereka untuk mengarahkan kliennya. Kita semua juga berfungsi membantu orang lain dalam interaksi interpersonal kita sehari-hari. Kita berkonsultasi dengan seorang teman yang putus cinta, berkonsultasi dengan mahasiswa tentang mata kuliah yang sebaiknya diambil dan lain sebagainya. Autis yang merupakan gangguan mental kejiwaan akan sangat terbantu dengan komunikasi interpersonal yang tepat dan berkelanjutan.

\section{PEMBAHASAN}

\section{Efektivitas Komunikasi Interpersonal}

Joseph DeVito (1997) menjelaskan tentang efektivitas Komunikasi Interpersonal dimulai dengan lima kualitas umum yang dipertimbangkan yaitu keterbukaan (openness), empati (empathy), sikap mendukung (supportiveness), sikap positif (positiveness), dan kesetaraan (equality) (Londa dan Boham, 2014).

Keterbukaan (Openness), kualitas keterbukaan mengacu pada sedikitnya tiga aspek dari komunikasi interpersonal. Pertama, komunikator interpersonal yang efektif harus terbuka kepada orang yang diajaknya berinteraksi. Ini tidaklah berarti bahwa orang harus dengan segera membukakan semua riwayat hidupnya.memang ini mungkin menarik, tapi biasanya tidak membantu komunikasi. Sebaliknya, harus ada kesediaan untuk membuka diri mengungkapkan informasi yang biasanya disembunyikan, asalkan pengungkapan diri ini patut.

Aspek keterbukaan yang kedua mengacu kepada kesediaan komunikator untuk bereaksi secara jujur terhadap stimulus yang datang. Orang yang diam, tidak kritis, dan tidak tanggap pada umumnya merupakan peserta percakapan yang menjemukan. Kita ingin orang bereaksi secara terbuka terhadap apa yang kita ucapkan. Dan kita berhak mengharapkan hal ini. Tidak ada yang lebih buruk daripada ketidak acuhan, bahkan ketidaksependapatan jauh lebih menyenangkan.

Kita memperlihatkan keterbukaan dengan cara bereaksi secara spontan terhadap orang lain. Aspek ketiga menyangkut "kepemilikan" perasaan dan pikiran (Bochner dan Kelly, 1974). Terbuka dalam pengertian ini adalah mengakui bahwa perasaan dan pikiran yang anda lontarkan adalah memang milik anda dan anda bertanggungjawab atasnya. Cara terbaik untuk menyatakan tanggung jawab ini adalah dengan pesan yang menggunakan kata Saya (kata ganti orang pertama tunggal).

Empati (empathy), Henry Backrack (1976) mendefinisikan empati sebagai "kemampuan seseorang untuk 'mengetahui' apa yang sedang dialami orang lain pada suatu saat tertentu, dari sudut pandang orang lain itu, melalui kacamata orang lain itu." Bersimpati, di pihak lain adalah merasakan bagi orang lain atau merasa ikut bersedih. Sedangkan berempati adalah merasakan sesuatu seperti orang yang mengalaminya, berada di kapal yang sama dan merasakan perasaan yang sama dengan cara yang sama. Orang yang empatik mampu memahami motivasi dan pengalaman orang lain, perasaan dan sikap mereka, serta harapan dan keinginan mereka untuk masa mendatang.

Kita dapat mengkomunikasikan empati baik secara verbal maupun non verbal. Secara nonverbal, kita dapat mengkomunikasikan empati dengan memperlihatkan (1) keterlibatan aktif dengan orang itu melalui ekspresi wajah dan gerak-gerik yang sesuai; (2) konsentrasi terpusat meliputi komtak mata, postur tubuh yang penuh perhatian, dan kedekatan fisik; serta (3) sentuhan atau belaian yang sepantasnya. 
Sikap mendukung (supportiveness), hubungan interpersonal yang efektif adalah hubungan dimana terdapat sikap mendukung (supportiveness). Suatu konsep yang perumusannya dilakukan berdasarkan karya Jack Gibb. Komunikasi yang terbuka dan empatik tidak dapat berlangsung dalam suasana yang tidak mendukung. Kita memperlihatkan sikap mendukung dengan bersikap (1) deskriptif, bukan evaluatif, (2) spontan, bukan strategik, dan (3) provisional, bukan sangat yakin.

Sikap positif (positiveness), Kita mengkomunikasikan sikap positif dalam komunikasi interpersonal dengan sedikitnya dua cara: (1) menyatakan sikap positif dan (2) secara positif mendorong orang yang menjadi teman kita berinteraksi. Sikap positif mengacu pada sedikitnya dua aspek dari komunikasi interpersonal. Pertama, komunikasi interpersonal terbina jika seseorang memiliki sikap positif terhadap diri mereka sendiri. Kedua, perasaan positif untuk situasi komunikasi pada umumnya sangat penting untuk interaksi yang efektif. Tidak ada yang lebih menyenangkan daripada berkomunikasi dengan orang yang tidak menikmati interaksi atau tidak bereaksi secara menyenangkan terhadap situasi atau suasana interaksi.

Kesetaraan (Equality), dalam setiap situasi, barangkali terjadi ketidaksetaraan. Salah seorang mungkin lebih pandai. Lebih kaya, lebih tampan atau cantik, atau lebih atletis daripada yang lain. Tidak pernah ada dua orang yang benar-benar setara dalam segala hal. Terlepas dari ketidaksetaraan ini, komunikasi interpersonal akan lebih efektif bila suasananya setara. Artinya, harus ada pengakuan secara diam-diam bahwa kedua pihak sama-sama bernilai dan berharga, dan bahwa masing-masing pihak mempunyai sesuatu yang penting untuk disumbangkan.

Dalam suatu hubungan interpersonal yang ditandai oleh kesetaraan, ketidak-sependapatan dan konflik lebih dillihat sebagai upaya untuk memahami perbedaan yang pasti ada daripada sebagai kesempatan untuk menjatuhkan pihak lain. Kesetaraan tidak mengharuskan kita menerima dan menyetujui begitu saja semua perilaku verbal dan nonverbal pihak lain. Kesetaraan berarti kita menerima pihak lain, atau menurut istilah Carl rogers, kesetaraan meminta kita untuk memberikan "penghargaan positif tak bersyarat" kepada orang lain.

\section{Model Komunikasi}

Fenomena komunikasi dapat digambarkan dengan lebih jelas melalui model komunikasi sebagaimana yang dijelaskan oleh Littlejhon In a broad a sense the term model can apply to any symbolic representation of a thing, process, or idea yaitu dalam pengertian luas, pengertian model menunjuk pada setiap representasi simbolis dari suatu benda proses gagasan/ide. Pada level konseptual model mempresentasikan ide-ide dan proses. Dengan demikian model komunikasi merupakan gambaran atau sebagai analogi dari berbagai fenomena komunikasi. Ada sejumlah model untuk menganalisa hubungan personal, tetapi dengan mengikuti ikhtisar dari Coleman dan Hammen (1974).

Model-model tersebut antara lain adalah sebagai berikut (Rakhmat, 1991): 1) Model pertukaran sosial yaitu model ini memandang hubungan interpersonal sebagai suatu transaksi dagang. Orang berhubungan dengan orang lain karena mengharapkan sesuatu yang memenuhi kebutuhannya; 2) Model peranan masyarakat yaitu model peranan melihatnya sebagai panggung sandiwara. Di sini setiap orang harus memainkan peranannya sesuai dengan naskah yang telah dibuat masyarakat. Hubungan interpersonal berkembang baik bila setiap individu bertindak sesuai dengan ekspedisi peranan dan tuntutan peranan, memiliki keterampilan peranan, dan terhindari dari konflik peranan dan kerancunan peranan; 3) Model permainan, dalam model ini orang-orang berhubungan dalam bermacam-macam permainan. Mendasari permainan ini adalah tiga bagian kepribadian manusia; 4) Model interaksional, model ini memandang hubungan interpersonal sebagai suatu sistem. Setiap sistem memiliki sifat-sifat struktural, integratif, dan medan. Semua sistem terdiri dari subsistem-subsisitem yang saling tergantung dan bertindak bersama sebagai suatu kesatuan. 


\section{Mengenal Gangguan Autisme}

Menurut Saharso, gejala autis biasanya sudah tampak sebelum anak berusia 3 tahun, yaitu antara lain dengan tidak adanya kontak mata dan tidak menunjukkan respons terhadap lingkungan. Kemudian Nurhayati menjelaskan bahwa permasalahan yang dihadapi oleh orang tua yang mempunyai anak autis antara lain : pada saat anak didiagnosis autis orang tua kaget, panik, bingung dan merasa bersalah, perasaan malu dan bingung untuk menjelaskan pada orang lain tentang keadaan anak, masalah biaya untuk perawatan, mengontrol emosi pada anak dan cara mengatasi anak pada saat anak tantrum (dalam kondisi marah), bingung mencari sekolah yang cocok untuk anak, dan khawatir terhadap masa depan anak (Wardanii, 2009).

Untuk menegaskan sebuah diagnosa bahwa seorang anak mengidap autisme, ada beberapa kriteria yang harus dipenuhi. Selama ini panduan yang dipakai oleh para dokter, psikiater, psikolog biasanya merajuk pada ICD-10 (International Classification of Diseases) 1993, atau yang mengunakan rumusan dalam DSM-IV (Diagnostic Statistical Manual) 1994 yang disusun oleh kelompok Psikiatri Amerika Serikat sebagai panduan untuk menegaskan diagnosa. Pada dasarnya diagnosa autisme yang ditegakkan berdasarkan ICD-10 atau DSM- IV menunjukan kriteria yang sama. Orang tua sebenarnya dapat mencoba mengecek sendiri apakah anaknya termasuk kategori autis atau tidak dengan memperhatikan kriteria autisme yang ada di dalam DSM - IV.

Beberapa kriteria seperti (Boham, 2013) : 1) Aspek sosial yaitu tidak mampu menjalani interaksi sosial yang memadai, seperti kontak mata sangat kurang hidup, ekspresi muka kurang hidup, ekspresi mata kurang hidup, dan gerak-geriknya kurang tertuju, serta tidak dapat bermain dengan teman sebaya; 2) Aspek Komunikasi yaitu sering menggunakan bahasa yang aneh dan berulang-ulang; 3) Aspek perilaku yaitu terpaku pada satu kegiatan yang ritualistik atau rutinitas yang tidak ada gunanya, dan seringkali sangat terpukau pada benda.

Indikator lain dari Autis yaitu : 1) Bahasa dan Komunikasi dimana ekspresi wajah yang datar, tidak menggunakan bahasa/isyarat tubuh, mengerti dan menggunakan kata secara terbatas/harafiah (literaly); 2) Hubungan dengan orang lain yaitu tidak responsif, tidak ada senyum sosial, tampak asyik bila dibiarkan sendiri; 3) Hubungan dengan lingkungan yaitu bermain repeatif (diulang-ulang), marah atau tak menghendaki perubahan-perubahan, berkembangnya rutinitas yang kaku (rigid); 4) Respon terhadap rangsangan indera/sensoris, yang ditandai kadang seperti tuli, panik terhadap suara-suara tertentu, atau mungkin memutarmutar, berputar-putar, membentur-benturkan kepala dan pergelangan; 5) Kesenjangan perilaku seperti menggambar secara rinci tapi tidak dapat mengancing baju, berjalan di usia normal tetapi tidak dapat berkomunikasi secara bahasa, suatu waktu dapat melakukan sesuatu tetapi tidak dilain waktu tidak.

Sedangkan dalam Diagnostic and Statistical Manual of Mental Disorders Fifth Edition (DSM5), terdapat kriteria-kriteria yang digunakan untuk menegakkan diagnosa autisme (Wijayaptri , 2015) yaitu : Pertama, adanya keterbatasan berkomunikasi dan berinteraksi sosial dalam berbagai konteks, yang termanifestasi dalam bentuk: 1) Keterbatasan dalam hubungan sosialemosional yang bersifat timbal-balik dengan orang lain, misalnya sulit atau tidak mampu bercakap-cakap dua arah, gagal memulai atau merespon interaksi sosial, sulit berbagi atau berempati; 2) Keterbatasan dalam komunikasi non verbal yang digunakan untuk berinteraksi sosial, misalnya gagal dalam mengintegrasikan komunikasi verbal dan non verbal, minim atau tidak adanya kontak mata, kesulitan dalam memahami dan menggunakan bahasa tubuh, adanya kekurangan yang menyeluruh dalam ekspresi wajah dan bentuk-bentuk komunikasi nonverbal lainnya; 3) Keterbatasan dalam membangun, menjaga, dan memahami hubungan sosial, misalnya sulit menyesuaikan perilaku sesuai dengan konteks sosial, sulit bermain imajinatif, sulit berteman, tidak memiliki ketertarikan pada teman sebaya.

Kedua, adanya pola perilaku, minat, dan aktivitas yang spesifik serta berulang-ulang, yang termanifestasi setidaknya dalam dua hal berikut: 1) Adanya gerakan motorik, penggunaan benda, atau perkataan yang diulang-ulang, misalnya simple motor stereotypies, menjejer-jejerkan 
mainan, echolalia, idiosyncratic phrases; 2) Adanya dorongan untuk melakukan perilaku verbal maupun nonverbal yang memiliki pola yang sama, menjadi rutinitas yang kaku, dan sulit untuk diubah, misalnya menunjukkan ketidaknyamanan saat mengalami perubahan-perubahan kecil, sulit mengalami transisi, pola berpikir yang rigid, adanya ritual atau kebiasaan menyapa, harus melalui rute yang sama atau makan makanan yang sama setiap hari; 3) Memiliki minat yang sangat terbatas dan menunjukkan abnormalitas dalam intensitas atau konsentasi, misalnya sangat lekat terhadap benda-benda yang tidak lazim; 4) Hipersensitif atau hiposensitif terhadap input sensoris, atau memiliki ketertarikan yang tidak lazim terhadap hal-hal yang ada di lingkungan sekitar, misalnya mengabaikan rasa sakit, memberi respon yang aneh terhadap suara atau tekstur tertentu, memiliki kesukaan yang berlebihan untuk mencium atau menyentuh benda tertentu, sangat terpesona dengan cahaya atau gerakan tertentu: Simptom-simptom harus muncul dalam periode perkembangan awal (akan tetapi dalam perkembangannya simptomsimptom tersebut dapat tertutupi atau berkurang karena adanya efek belajar); Simptomsimptom tersebut mengakibatkan gangguan yang signifikan dalam aspek sosial, perkerjaan, atau aspek-aspek penting lainnya dalam kehidupan; Gangguan-gangguan ini akan lebih baik jika tidak disebut sebagai intellectual disability (intellectual developmental disorder) atau global developmental delay. Intellectual disability dan autisme dapat muncul secara bersamaan. Untuk membuat diagnosa komorbid antara autisme dan intellectual disability, kemampuan komunikasi sosial harus berada di bawah tahap perkembangan normal.

\section{Model Komunikasi Interpersonal Terhadap Anak Autis}

Setidaknya ada 3 kemampuan dasar yang terus diperhatikan oleh orang tua kepada anak gangguan autis diantaranya (Boham, 2013): pertamakemampuan kontak mata (visual-learners) sama pentingnya dengan kepatuhan. Kontak mata yang baik dan lama akan sangat memudahkan proses terapi. Pertama perlu diingat bahwa kontak mata akan mudah tercipta bila ada kehangatan dan kedekatan hubungan antara dua individu. Oleh karena itu anda perlu membangkitkan rasa kasih sewaktu anda akan memulai terapi. Jangan berpura-pura, karena anak autis sangat peka/sensitive pandangan matanya.

Kedua, kemampuan bahasa reseptif (kognitif) adalah kemampuan pengenalan akan beragam atau hal. Kemampuan ini disebut juga identifikasi dan dapat berlanjut ke kemampuan melabel, kemudian kemampuan bahasa ekspresif. Bagi anak-anak dengan daya tangkap yang baik, pada saat diajarkan kemampuan bahasa reseptif, dapat dilanjutkan dengan kemampuan ekspresif. Akan tetapi pada anak-anak dengan daya tangkap lemah, sebaiknya kedua kemampuan ini diajarkan terpisah. Ketiga, mengajarkan bahasa ekspresif adalah memberikan kemampuan pada anak untuk mengingat dan menggali hal-hal yang sudah terekam dalam memorinya untuk diekspresikan. Oleh karena itu, kemampuan ini harus diajarkan setelah konsep meniru dan konsep bahasa kognitif sudah cukup dikuasai anak.

Program-program penanganan untuk terapi wicara bagi anak autis ini akan sangat membantu orang tua/keluarga dalam melakukan komunikasi dengan anak autis, oleh karena itu orang tua sangat perlu memiliki buku pedoman pengananan dan berusaha menguasai serta memahaminya sehingga dapat dilaksanakan di rumah bersama anggota keluarga besar yang turut membantu penanganan anak.

Meyakinkan sang anak bahwa lingkungan sekitarnya peduli dan selalu memperhatikan dirinya dalam hal ini orang tua membiasakan untuk mengajak anak berinteraksi dengan keluarga terdekat seperti adik, kakak, abang, maupun dengan anak tetangga yang sebaya. Hal ini membantu anak terbiasa untuk mengenali informasi dari pihak luar sehingga gangguan aspek sosialnya mulai berkurang. Mengajarkan dan membiasakan anak yang terkena autis untuk menganal banyak kosakata yang tepat dan baik, kemudian memberikan teguran jika anak sering menggunakan bahasa yang aneh dan berulang-ulang. Hal ini akan membuat sang anak sadar bahwa mengulang kata yang aneh-aneh merupakan hal yang tidak tepat dan baik. Mengajak sang anak untuk melakukan aktifitas yang sifatnya tidak mengulang atau rutinitas dengan melatih sedari awal untuk melakukan aktifitas baru atau pengalaman baru misalnya menggambar 
diselingi mengambil barang yang sesuai, mengenal berbagai tumbuh-tumbuhan dan hewanhewan, dengan cara berwisata alam.

Menggunakan model pertukaran sosial, dimana hubungan interpersonal yang dilakukan sebagai suatu transaksi antara pihak A dan B dalam hal ini orang tua dengan anaknya dengan membuat model komunikasi yang sifatnya dapat memenuhi kebutuhan satu sama lainnya, memberikan reward kepada sang anak jika berhasil keluar dari tanda-tanda autisme. Sebagai contoh; ketika sang anak mampu mengontrol kontak mata atau pandangannya kepada orang lain, atau ketika sang anak mampu mengurangi pengucapan kosakata yang tidak jelas maknanya, tidak melakukan gerakan-gerakan yang tidak normal. Model ini memberikan penekanan bahwa hubungan interpersonal sifatnya timbal-balik menyesuaikan kebutuhan antar pihak yang berbicara.

Menggunakan model permainan, yang menekankan sebuah hubungan interpersonal bisa dilakukan menggunakan macam-macam permainan. Setidaknya ada beberapa elemen dalam sebuah permainan, yaitu pemain, strategi/cara main, dan imbalan. Orang tua dapat membuat dalam bentuk sebuah quiz atau tantangan yang harus dilakukan untuk melatih pemahanan, daya tangkap, kemampuan motorik, dan juga kemampuan komunikasi. Contohnya : bermain puzzle bergambar, disertai dengan melekatkan jenis suara yang mewakili gambar yang tertera pada puzzle untuk kemudian dicontoh oleh sang anak. Model interaksi seperti ini banyak dilakukan pada program sekolah berkebutuhan khusus, bedanya jika ini dilakukan oleh orang tua maka daya pengaruhnya akan berbeda jika ditempat umum dan banyak orang seperti sekolah khusus. Kebanyakan orang tua hanya mengandalkan penanganan kemampuan wicara anak hanya di sekolah oleh guru-guru bahkan ada orang tua yang hanya mempercayakan penanganan anak untuk melatih kemampuan berkomunikasi kepada guru tanpa diulang dirumah oleh orang tua secara langsung.

\section{SIMPULAN}

Orang tua harus mampu keluar dari perasaan kekecewaan dan kesedihan serta kebingungan atau bahkan muncul rasa malu. Karena tumbuh kembangnya anak autis sangat bergantung dari kepercayaan diri orang tuanya dalam menghadapi berbagai tingkah laku serta memahami apa yang diinginkan oleh sang anak. Tidak menutup-nutupi keadaan buah hati mereka dari lingkungan sekitarnya dengan mengurung anak di dalam rumah bahkan kamar tertentu, serta mengucilkan anak dari lingkungan luar. Hal ini akan menghambat proses pertumbuhan interaksi anak kepada dunia luar, sehingga anak diajak bersosialisasi seperti halnya anak-anak yang lain. Hal ini akan membantu anak mengenal lebih banyak kosa kata baru, pengalamanan fenomena baru. Model komunikasi yang digunakan hendaknya mempertimbangkan sejauh mana bentuk gangguan autis yang dialami sang anak, dengan demikian banyak tidaknya penggunaan model komunikasi menyesuaikan keadaan.

\section{DAFTAR PUSTAKA}

Boham, S.E. (2013). Pola Komunikasi Orang Tua Dengan Anak Autis; Studi pada orang tua dari anak autis di Sekolah Luar Biasa AGCA Center Pumorow Kelurahan Banjer Manado, Journal Volume II. No. 4. Tahun 2013.

Liliweri, A. (2011). Dasar-dasar Komunikasi Antarbudaya. Yogyakarta : Pustaka Pelajar, 2011.

Londa, B.N. Senduk, J. Boham, A. (2014). Efektivitas Komunikasi Antar Pribadi Dalam Meningkatkan Kesuksesan Sparkle Organizer, Journal Vol. III, No.1. Tahun 2014.

Muhammad, A. (2005). Komunikasi Organisasi, Jakarta: Bumi Aksara.

Nida, F.L.K. (2013). Komunikasi Bagi Anak Berkebutuhan Khusus. STAIN Kudus : At-Tabsyir. Jurnal Komunikasi Penyiaran Islam). Vol. 1, No. 2, Juli - Desember 2013.

Rakhmat, J. (1991). Psikologi Komunikasi, Bandung : Remaja Rosdakarya.

Wardani, D.S. (2009). Strategi Coping Orang Tua Menghadapi Anak Autis, (Universitas Muhammadiyah Surakarta : Indigenous, Jurnal Ilmiah Berkala Psikologi) Vol. 11, No. 1, Mei 2009.

Wijayaptri, N.W.P. (2015). Hambatan Komunikasi Pada Penyandang Autisme Remaja: Sebuah Studi Kasus. (Universitas Gadjah Mada : INKLUSI). Vol. 2, No. 1 Januari - Juni 2015. 
Syahrul Abidin. Model Komunikasi Interpersonal Orangtua terhadap Anak Autis

Yohannawati, D. (2013). Pengaruh Perbedaan Budaya Terhadap Proses Komunikasi Interpersonal Pengaruh Perbedaan Etnis Tionghoa - Jawa dan Agama Islam - Kristen dalam Berpacaran, Salatiga : Universitas Kristen Satya Wacana, 2013.

Suharyanto, A. Matondang, A. Walhidayat, T. (2017). The Interpersonal Communication of the Chinese Ethnic Families in Cheng Beng Ceremony in Medan, Indonesia, IOSR Journal Of Humanities And Social Science (IOSR-JHSS) Volume 22, Issue 12, Ver. 4 (December. 2017) PP 38-44. 